\title{
GAMBARAN KADAR HEMOGLOBIN PADA SUPIR BUS DI PANGKALAN BUN BERDASARKAN DURASI TIDUR
}

\author{
Rena Agustina ${ }^{1)}$, Iqlila Romaidha, ${ }^{2)}$, Nur Aini Hidayah Khasanah ${ }^{3)}$ \\ ${ }^{1,2,3}$ Stikes Borneo Cendekia Medika Pangkalan Bun \\ renaagustina165@gmail.com
}

\begin{abstract}
ABSTRAK
Hemoglobin merupakan protein yang kaya akan zat besi yang terdapat di sel darah merah yang berfungsi menstranspor oksigen keseluruh tubuh. Faktor yang dapat mempengaruhi kurangnya kadar hemoglobin pada manusia diantaranya adalah kurang tidur pada malam hari, hal ini dapat menyebabkan produksi sel darah merah berkurang. Sedangkan faktor lain yang dapat meningkatkan kadar hemoglobin adalah perokok dengan kategori berat, hal ini di karenakan karbon monoksida mempunyai afinitas yang kuat terhadap hemoglobin sehingga oksigen yang seharusnya berikatan dengan hemoglobin menjadi rendah. Adapun tujuan dari penelitian ini adalah untuk mengetahui gambaran kadar hemoglobin pada supir bus berdasarkan durasi tidur di Pangkalan Bun.Teknik pengambilan sampel dalam penelitian ini menggunakan total sampling. Metode yang digunakan dalam pemeriksaan ini menggunakan metode Cyanmethemoglobin, kelebihan metode ini karna pemeriksaannya akurat dan reagen serta alat untuk mengukur kadar hemoglobin dapat dikontrol dengan larutan standar yang stabil. Penelitian ini merupakan penelitian deskriptif dengan desain penelitian Croos Sectional. Pengolahan data menggunakan software SPSS versi 20. Berdasarkan hasil penelitian ini menunjukkan kadar hemoglobin dari 32 responden untuk kadar hemoglobin normal pada supir sebanyak 14 responden, kadar hemoglobin rendah rendah sebanyak 13 responden dan kadar hemoglobin tingi sebanyak 5 resonden.

Supir bus yang memiliki kadar hemoglobin dengan durasi tidur $\leq 7$ jam sebagian besar $15(21,87 \%)$ memiliki kadar hemoglobin normall.
\end{abstract}

Kata Kunci : Hemoglobin, Supir Bus, Durasi Tidur, Cross Sectional

\begin{abstract}
Hemoglobin or haemoglobine, iron containing protein in red blood cells that transport oxygen to the body. Factors can be affect of low hemoglobin levels in humans include sleep deprivation at night. The effect is decrease production of red blood cells. Factors that can increase hemoglobin levels are heavy smokers, this is because carbon monoxide has a strong affinity for hemoglobin so that the oxygen that should bind to hemoglobin is low. The purpose of this study to describe hemoglobin levels of bus drivers based on the sleep duration in Pangkalan Bun. The sampling technique used to total sampling. The methods of examination used Cyanmethemoglobin method. The advantages of Cyanmethemoglobin method is accurate and the reagents for measuring hemoglobin levels can be controlled with a stable standard solution. This research is a descriptive study with a Croos Sectional research design. Data processing used SPSS version 20. Based on results of this study, the hemoglobin levels of 32 respondents for normal hemoglobin levels in the driver were 14 respondents, low hemoglobin levels were 13 respondents and high hemoglobin levels were 5 respondents. Most of the 15 bus drivers who had hemoglobin levels with a sleep duration of $\leq 7$ hours $(21.87 \%)$ had normal hemoglobin levels
\end{abstract}

Keywords: Hemoglobin level, sleep duration, cigarette consumption, cross sectional 


\section{PENDAHULUAN}

Hemoglobin merupakan protein yang kaya akan zat besi yang terdapat di sel darah merah. Hemoglobin memiliki afinitas (daya gabung) terhadap oksigen membentuk oksihemoglobin di dalam sel darah merah (Evelyn, 2011). Hemoglobin terdiri dari materi yang mengandung zat besi heme dan protein globulin. Terdapat sekitar 300 molekul hemoglobin dalam satu sel darah merah. Setiap molekul hemoglobin memiliki empat tempat pengikatan untuk oksigen. Oksigen yang terikat dengan hemoglobin disebut oksihemoglobin. Hemoglobin memiliki tugas mengedarkan $\mathrm{O}_{2}$ ke seluruh tubuh dan menyerap karbon dioksida serta ion hidrogen membawanya ke paru, lalu zat tersebut di lepaskan ke udara. Terdapat paling sedikit 100 jenis molekul hemoglobin abnormal pada manusia yang terbentuk akibat berbagai mutasi. Mutasi hemoglobin diakibatkan karena molekulnya membawa oksigen dalam jumlah sedikit (Elizabeth, 2009)..

Pembentukan hemoglobin memerlukan bahan-bahan penting, yaitu zat besi (Fe), vitamin B12 (siano-kobalamin) dan asam folat (asam pteroilglutamat). Diperlukan $1 \mathrm{mg}$ zat besi untuk setiap mililiter $(\mathrm{ml})$ eritrosit yang diproduksi. Setiap hari 20-25 $\mathrm{mg}$ besi diperlukan untuk pembentukan eritrosit (eritropoiesis) sebanyak 95\% didaur ulang dari zat besi yang berasal dari perputaran eritrosit dan katabolisme hemoglobin. Jika kekurangan zat besi (Fe), pembelahan sel akan menghasilkan sel-sel eritrosit yang berukuran lebih kecil dan menyebabkan penurunan jumlah hemoglobin (Riswanto, 2013).

Menurut penelitian John W. Adamson (2005) menyatakan perokok berat mengalami peningkatan kadar hemoglobin. Peningkatan ini terjadi karena reflek dari mekanisme kompensasi tubuh terhadap rendahnya kadar oksigen yang berikatan dengan hemoglobin akibat digeser oleh karbon monoksida yang mempunyai afinitas terhadap hemoglobin yang lebih kuat. Sehingga tubuh akan meningkatkan proses hematopoiesis lalu meningkatkan produksi hemoglobin, akibat dari rendahnya tekanan parsial oksigen $\left(\mathrm{PO}_{2}\right)$ di dalam tubuh (Makawekes et al., 2016).

Faktor yang dapat mempengaruhi kurangnya kadar hemoglobin pada manusia salah satunya adalah kurang tidur pada malam hari, hal ini dapat menyebabkan produksi sel darah merah berkurang. Selain itu faktor yang mempengaruhi kadar hemoglobin adalah fisik yang kurang. Kondisi ini berpengaruh terhadap keseimbangan energi dalam tubuh sehingga meningkatkan risiko kelebihan badan dan kurangnya aktivitas fisik dapat mengakibatkan hipertensi dan kadar hemoglobin yang tidak normal, serta berbagai komplikasi penyakit yang lain (Prima et al., 2017).

Hingga saat ini, penelitian tentang Analisa darah terutama kadar haemoglobin pada supir bus jarak jauh di pangkalan bun belum pernah dilakukan. Berdasarkan latar belakang di atas, peneliti tertarik untuk melakukan penelitian 
dengan judul " Gambaran Kadar Hemoglobin pada Supir Bus di Pangkalan Bun Berdasarkan Durasi Tidur"

\section{METODE PENELITIAN}

$\begin{array}{ccr}\text { Pada } & \text { pemeriksaan } & \text { hemoglobin } \\ \text { menggunakan } & \text { metode } & \text { Fotometrik }\end{array}$

1. Menyiapkan dua buah tabung

2. Masing-masing tabung di isi dengan 5 $\mathrm{ml}$ larutan drabkin, satu sebagai blangko dan yang satu sebagai test

3. Hisaplah darah dengan pipet hemoglobin sampai garis tada $0,02 \mathrm{ml}$

4. Hapuslah darah yang melekat pada sebelah luar ujung pipet

5. Alirkan darah dari pipet ke salah satu tabung yang berisi larutan drabkin. Bilas pipet dengan larutan drabkin yang jernih 2 sampai 3 kali untuk membersihkan

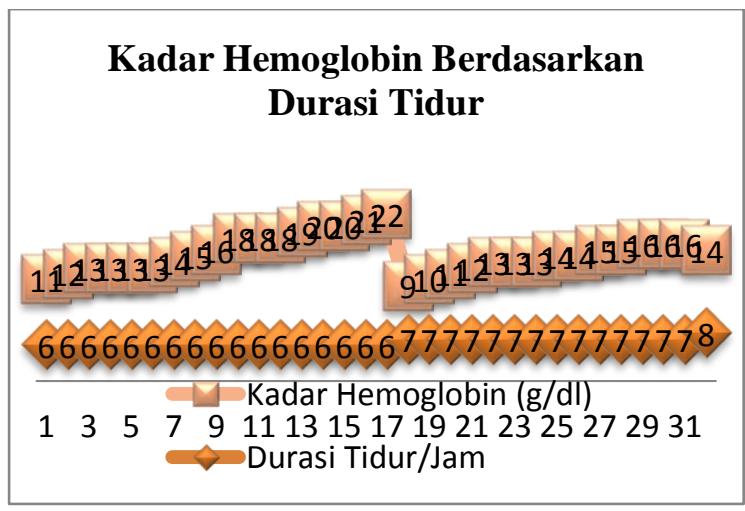

Gambar5.2. Kadar Hemoglobin Responden Berdasarkan Durasi Tidur.

Keterangan :

Pada Gambar 5.2. didapatkan kadar hemoglobin responden berdasarkan durasi

Berdasarkan hasil yang didapatkan, kadar hemoglobin tertinggi yaitu pada Tn. Gu dan Tn. Ar memiliki kadar hemoglobin
Syanmethemoglobin, alat yang digunakan yaitu spektrofotometer, tourniquet, rak tabung, tabung vakum, spuit $3 \mathrm{cc}$, EDTA, kapas alkohol, kapas kering dan untuk bahan yang digunakan adalah darah vena dan reagen Drabkin.

Cara kerja atau prosedur kerja : darah yag masih tertinggal di dalan pipet

6. Homogenkan isi tabung sampai merata. Inkubasi suhu ruang selama 5 menit

7. Bacalah kadar hemoglobin pada alat spektrofotometer $(\mathrm{g} / \mathrm{dl})$ dengan panjang gelombang $546 \mathrm{~nm}$

Nilai Nornal : 14-18 g/dl

\section{PEMBAHASAN}

Gambar 5.2. didapatkan pada kadar hemoglobin responden berdasarkan durasi tidur.

tidur dengan jumlah responden sebanyak 32 orang, pada durasi tidur 6 jam dengan responden sebanyak 17 orang, mengalami peningkatan kadar hemoglobin dengan kadar hemoglobin paling tinggi adalah $22 \mathrm{gr} / \mathrm{dl}$ dan kadar paling rendah adalah $11 \mathrm{gr} / \mathrm{dl}$ dan untuk durasi tidur antara 7 jam dengan responden sebanyak 14 orang dengan kadar tertinggi 16 gr/dl dan kadar terendah 9 gr/dl. Durasi tidur 8 jam dengan jumlah responden 1 orang adalah 14 r/dl. Kadar normal untuk laki-laki yaitu $14-18 \mathrm{gr} / \mathrm{dl}$.

sebesar $20 \mathrm{gr} / \mathrm{dl}$ dengan durasi tidur sebesar 6 jam berdasarkan jumlah konsumsi rokok, Tn Ar memiliki kebiasaan konsumsi rokok 
sebanyak 11 batang/hari, hal ini berbanding lurus dengan penelitian yang dilakukan oleh Makawekes et al (2016) yang menegaskan bahwa peningkatan kadar hemoglobin terjadi pada perokok berat akibat reflek dari mekanisme kompensasi tubuh terhadap rendahnya kadar oksigen yang berikatan dengan hemoglobin akibat digeser oleh keberadaan karbon monoksida yang memiliki ikatan lebih kuat dibandingkan oksigen. Sehingga, tubuh akan melakukan proses hematopoiesis lalu meningkatkan produksi hemoglobin.

Kadar hemoglobin tertinggi selanjutnya adalah Tn. Su dan Ru memiliki kadar hemolobin sebear 21 dan 22 gr/dl dengan durasi tidur 6 jam pada Tn Ru dan $\mathrm{Su}$ setelah diakukan observasi memiliki riwayat dehidrasi. Probandus ketika darahnya diambil dalam proses pengambilan sampel darah dengan penggunaan spuit sulit, dikarenakan pasien mengalami dehidrasi. Menurut Falista (2017) kadar hemoglobin tinggi abnormal terjadi karena keadaan hemokonsentrasi akibat dari dehidrasi atau kehilangan cairan. Berdasarkan observasi dengan Tn $\mathrm{Ru}$ dan Su yang jarang sekali minum air putih menyebabkan hemokonsentrasi sehingga kadar hemoglobin menjadi tinggi.
Selanjutnya, pada hasil didapatkan responden yang memiliki kadar hemoglobin normal yaitu sebanyak 14 probandus dengan durasi tidur rata-rata sebesar 7 jam dikaitkan dengan Tn. Ta adalah laki-laki yang memiliki umur 20 tahunan intensitas makanan yang normal. Menurut Hawkins et al (2019) Pada laki laki berumur 20-30 dengan intensitas makanan yang normal dan metabolisme tubuh yang masih baik kadar hemoglobin yang ada di dalam tubuh rata-rata sebesar 14,4-15 g/dl. Tn. Ta merupakan probandus yang paling muda yaitu berumur 28 tahun dengan berat badan normal dan aktivitas fisik yang sedang. Sehingga, kadar hemoglobin menunjukan niai yang normal.

Bedasarkan hasil penelitian kadar hemoglobin terendah yaitu pada Tn. Us dengan kadar hemoglobin sebesar 9 gr/dl. Dengan durasi tidur 6 jam. Namun. Menurut hasil observasi dan perhitungan Body Mass Index (BMI), Tn. Us mengalami obesitas. Menurut Heryati dan Budi (2014), Obesitas berhubungan dengan terjadinya inflamasi sistemik yang berdampak negatif dengan rekulasi zat besi yang menyebabkan terjadinya defisiensi zat besi, jika berangsur lama akan menyebabkan anemia. Selain itu, Tn. Us memiliki kadar hemoglobin rendah dikarenakan Tn us lebih banyak mengonsumsi makanan berlemak. Sedangankan, untuk mencukupi 
kebutuhan gizi dalam peningkatan jumlah hemoglobin dan anemia harus mengonsumsi sayuran dan buah-buahan yang kaya akan zat besi (Kusumawati et al., 2019).

Berdasarkan Tabel 5.1 pada responden yang memiliki kadar hemoglobin di bawah normal sebanyak $40 \%$ tidur malam idealnya harus di lakukan selama 8 jam, hal itu bertujuan agar sistem kerja tubuh dapat berjalan maksimal pada keesokan harinya. Karena hormon pertumbuhan manusia dan hormon kortek adrenal yang sangat penting untuk menunjang system metabolisme tubuh serta perkembangan fungsi otot di hasilkan pada malam hari. Jika seseorang sering sampai kekurangan tidur malam, ini berarti akan mengganggu tubuh kita untuk menghasilkan kedua hormon tersebut, yang nantinya akan terdampak serius bagi kondisi kesehatan kita, diantaranya adalah penyakit kekurangan darah atau anemia, hal ini disebabkan karena hormon dan produksi sel darah merah terganggu akibat metabolisme tubuh yang tidak seimbang (Zarianis, 2006).

Kadar hemoglobin rendah terdapat 13 responden. Terdapat 4 responden yaitu $\mathrm{Tn}$. $\mathrm{Ma}, \mathrm{Bu}, \mathrm{Yu}$ dan Sa memiliki kadar hemoglobin rendah berdasarkan jam tidurnya. Sedangkan, menurut penelitian terdahulu merokok adalah faktor resiko terjadinya sindroma myelodisplastik yang salah satu gejalanya adalah anemia. Maka secara tidak langsung dikatakan merokok bisa menyebabkan terjadinya penurunan kadar hemoglobin darah, Berdasarkan informasi diatas, diketahui bahaya merokok mempunyai hubungan dengan kadar hemoglobin darah di dalam tubuh (Asyraf, 2010).

Sedangkan, kadar hemoglobin terendah dengan durasi tidur 6 jam untuk Tn. Ma, Bu dan Yu. Hal ini dikarenakan Tidur dan istirahat merupakan kebutuhan dasar yang dibutuhkan setiap orang, agar tubuh dapat berfungsi dengan normal. Saat istirahat, tubuh melakukan proses pemulihan yang sangat bermanfaat untuk mengembalikan stamina tubuh hingga berada dalam kondisi yang optimal (Setyandari, 2016). Seseorang yang mengalami anemia dengan kualitas tidur yang buruk dapat memperparah kondisi anemianya. Selain itu, kualitas tidur yang buruk pada penderita anemia juga dapat memicu terjadinya depresi dan penyakit psikologis lainnya jika tidak segera ditangani dengan cepat. Rata-rata penderita anemia mengalami kualitas tidur yang buruk, sehingga hal tersebut dapat memperparah kondisi anemianya. Indikator dari kualitas tidur adalah durasi waktu tidur (Murat et al (2015) dalam Fitriyana et al (2019)).

Waktu tidur sangat berhubungan dengan irama sirkadian, siklus sirkadian adalah proses berputar dari terang ke gelap dan kembali lagi setiap 24 jam, dan kebanyakan spesies yang hidup di permukaan bumi telah beradaptasi dengan perubahan reguler dalam lingkungannya. Dalam proses kehidupannnya, manusia memanfaatkan cahaya di sianghari untuk mengukur berbagai kebutuhan biologisnya dan setelah itu mereka banyak tidur di malam hari (Wisnubrata, 2016). Menurut observasi penampakan wajah pada resonden yang memiliki kadar hemoglobin 
rendah tampak lesu. Menurut WHO (2004) dalam Palinggi (2017) kualitas tidur seseorang dapat digambarkan dari keluhan - keluhan saat sebelum mereka tidur dan setelah mereka tidur seperti tampak lesu dan pucat .

Anemia dapat meyebabkan berkurangnya kadar hemoglobin yang mengikat oksigen di dalam darah. Hal ini menyabkan terjadinya ganguan tidur pada penderita terutama dengan komplikasi penyakit tertentu. Anemi asangat berhubungan dengan penyakit cardiovaskular dan kematian. Anemia yang mengalami komplikasi pada ginjal, ginjal mengalami kerusakan yang disebabkan oleh peradangan pada ginjal tersebut sehingga terjadi peninkatan sitokin proinflamasi IL6 yang akan meningkatkan produksi hepcidin oleh hepatosit. Hepsidin merupakan protein tipe II yan diproduksi di hati yang berfungsi meningkatkan homeostasis zat besi di dalam tubuh dan disekresikan pada sirkulasi darah (Palinggi, 2017).

Menurut penelitian Liu et al (2018) perempuan dengan durasi tidur yang panjang berpotensi meningkatkan resiko anemia, tetapi pada laki-lai dengan durasi tidur yang panjang akan menurunkan resiko anemia. Hal ini dikaitkan dengan sekresi hormonal dan faktor fisiologis dari hormon.

Dalam penelitian ini terdapat kelemahan yakni beberapa sampel diambil di siang hari atau sore hari tanpa adanya puasa pada responden. Hal ini dikarena keterbatasan waktu antara responden. Responden merupakan Supir Bus antar kota dan provinsi sehingga waktu untuk pengambilan darah tidak dapat ditentukan karena waktu bergantung dengan kedatangan bus. Menurut kackov et al (2013) di laboratorium pemeriksaan hematologi memberikan instruksi pada pasien yaitu pengambilan sampel pada pagi hari berkisar pukul 7 sampai 9 pagi setelah 12 jam puasa, pada masa puasa hanya boleh mengkonsumsi air putih. Ketika waktu puasa kurang dari 12 jam akan sangat krusial untuk pasien mendapatkan informasi dan kualitas yang akurat dari pemeriksaan yang mereka lakukan.

Data yang diperoleh dilakukan uji statistik deskriptif mengunakan software SPSS versi 20. Dari hasil uji statistik deskriptif yang telah dilakukan dari 32 sampel yang telah diteliti didapatkan rata-rata kadar hemoglobin sebesar 14,88 g/dl, nilai tengah (median) dari data tersebut adalah 14,00 g/dl. Nilai minimum dari pemeriksaan kadar hemoglobin adalah sebesar $9 \mathrm{~g} / \mathrm{dl}$ dan nilai maksimum dari dari pemeriksaan kadar hemoglobin sebesar 21 g/dl. Pengujian Skewness didapatkan hasil sebesar 0,394 nilai yang didapatkan tersebut masih terletak antara -1 sampai +1 yang berarti data berdistribusi normal. Kurtosis merupakan angka statistik yang memberikan distribusi lebih tinggi atau lebih pendek dari distribusi normal, pengujian kurtosis sebesar 0,518 nilai yang didapatkan mengindikasikan dengan distribusi normal (Wuensch, 2019).

\section{KESIMPULAN}

Berdasarkan hasil penelitian gambaran kadar hemoglobin pada supir bus di Pangkalan Bun berdasarkan durasi tidur dapat diambil kesimpulan bahwa dari 32 responden, sebanyak $37,5 \%$ memiliki kadar hemoglobin 
normal, 34,37 \% memiliki kadar hemoglobin rendah dan $15,62 \%$ memiliki kadar hemoglobin tinggi.

\section{SARAN}

Diharapkan masyarakat khususnya yang bekerja sebagai supir bus dapat menjaga kadar hemoglobin dengan durasi tidur yang cukup dan menghindari merokok dan Melalui penelitian ini diharapkan bagi peneliti selanjutnya mengembangkan penelitiannya dengan memperhatikan penyakit yang mendasari sebagai faktor yang dapat meningkatkan kadar hemoglobin.

\section{DAFTAR PUSTAKA}

Arbianti, Fitri. 2016. Gambaran Kadar Hemoglobin Penjual Makanan Pada Malam Hari di Wilayah Anduonohu Kec.Poasia Kota Kendari Provinsi Sulawesi Tenggara. Karya Tulis Ilmiah. Poltekes Kendari.

Asyraf, Ahmad B, Z. 2010. Hubungan Merokok Dengan Kadar Hemoglobin Darah Pada Warga Dengan Jenis Kelamin Laki-laki Berusia 18-40 Tahun yang Tinggal di Bandung Putra Betam Kepala Batas Pulau Pinang Malaysia. Skripsi. Sarjana Kedokteran. Fakultas Kedokteran. Universitas Sumatra Utara. Medan

Basuki, A. T. 2014. Penggunaan SPSS Dalam Statistik. Penerbit Danisa Media. Yogyakarta

Chairlain dan Estu Lestari 2011. Pedoman Teknik Dasar Untuk Laboratorium Kesehata., EGC. Jakarta.

Elisabeth. 2009. Buku Saku Patofisiologi. Penerbit buku. EGC. Jakarta.

Falista, Haniffa Novenia. 2017. Perbedaan Kadar Hemoglobin Sesudah dan Sebelum Mengonsumsi Tablet FE Pada Ibu Hamil Tresemester II Di Puskesmas Kendungmendu. Skripsi. Universitas Muhammadiah Semarang.
Hasanan, Faridatul. 2018. Hubungan Kadar Hemoglobin dengan Daya Tahan Kardiovaskuler pada Atlet Atletik FIK Universitas Negeri Makassar. Jurnal Olahraga dan Kesehatan. (1)1:1-16.

Hidayat, A. A. 2014. Metode Penelitian Keperawatan dan Teknis Analisi Data. Selemba Medika. Jakarta.

Kanmanna, Oman. 2008. Buku Ajar Biologi. Gravindo Medika Pratama. Bandung.

Khasanah, Uswatun dan Nindya. 2018. Hubungan Antara Kadar Hemoglobin dan Status Gizi dan Produktivitas Pekerja Wanita di Bagian Percetakan dan Pengemasan di UD x Sidoarjo. Jurnal Amerta Nutrition. (83) 83-89.

Kementrian Kesehatan Republik Indonesia. 2014. Data dan Informasi Kesehatan Jawa Timur. Pusat Data dan Informasi Kemenkes RI. Jakarta.

Kentarsih, Atun dan Sumirah, Atun, Farihatun. 2015. Gambaran Kadar Hemoglobin Pada Pasien Hipertensi Di Ruangan Kenanga Rumah Sakit Umun Daerah Ciamis. Karya Tulis Ilmiah. Jakarta.

Kusumawati E, Rahardjo S \& Sari HP. 2019. Model Pengendalian Faktor Stunting pada Anak Usia Dibawah Tiga Tahun. Jurnal Kesehatan Nasional.

Makawekes, T. Melkior.,Sonny J. R.K. dan Taufiq, F. P. 2016. Perbandingan Kadar Hemoglobin Darah Pada Pria Perokok dan Bukan Perokok. Jurnal e-Biomedik. Universitas Sam Ratulangi Manado.

Mutaqqin, Arif. 2019. Buku Ajar Asuhan Keperawatan Klien dengan Gangguan Sistem Pernapasan. Penerbit Salemba Medika. Jakarta.

Muhammad, Affan. 2012. Rancang Bangun Sistem Pengukuran Kadar Hemoglobin Darah Berbasis Mikrokontroler. Sripsi. Universitas Airlanga.

Murwani, A. 2009. Perawatan Pasien Penyakit Dalam. Mitra Cendekia Press. Yogyakarta. 
Nugrahani, Ika. 2013. Perbedaan Kadar Hemoglobin Sebelum dan Sesudah Menstruasi Mahasiswa DIII Keperawatan Universitas Muhammadiyah Surakarta. Karya Tulis Ilmiah. Universitas Muhammadiyah Surakarta.

Nugraha, Gilang. 2015. Panduan pemeriksaan laboratorium hematologi dasar. CV. Trans Info Media. Jakarta.

Notoatmodjo, Soekidjo. 2010. Metodelogi Penelitian Kesehatan. Rineka Cipta. Jakarta.

Norsiah,W.2015. Perbedaan kadar hemoglobin metode sianmethemoglobin dengan dan tanpa sentrifugasi pada sampel leukositosis. Journal medical laboratory technology.

Nursalam. 2016. Konsep dan Penerapan Metode Penelitian Ilmu Keperawatan. Salemba Medika. Jakarta.

Palinggi, Yunita. 2017. Perubahan Kadar Hemoglobin Dan Ureum Terhadap Kualitas Tidur Pasien. Skripsi. Universitas Hasanudin. Makasar.

Pearce, C., 2011. Anatomi dan fisiologi untuk paramedis. Gramedia Pustaka Utama. Jakarta.

Permatasari,.V. 2017. Pengaruh Perokok Aktif dan Perokok Pasif Terhadap Kadar Hemoglobin. Karya Tulis Ilmiah. STIKes Insani Cendekia Medika Jombang.

Pramono, 2017. Rancangan Penelitian di Bidang Kesehatan. Universitas Gajah Mada. Yogyakarta.

Prima, Dian.Ari dan Sakundon. 2017. Gambaran Faktor yang Berhubungan dengan Kejadian Hipertensi pada Sopir Angkuran Kota. Jurnal Kesehatan Masyarakat. 2(5).

Riswanto. 2013. Pemeriksaan Laboratorium Hematologi. Alfamedia \& Kanal Medika. Yogyakarta.
Saputro, Dwi.Aries \& Said, Junaidi. 2015. Pemberian Vitamin C pada Latihan Fisik Maksimal dan Perubahan Kadar Hemoglobin dan Jumlah Eritrosit. Journal of Sport Science and Fitness. (3) 4 .

Singh,. \& Kathiresan. 2015. Effect of Ciggarete of Smoking Human Health and Promising Remedy by Mangroves. Elsevier journal. (2)5:163.

Sugiyono. 2011. Metode Penelitian Kualitatif dan $R \& D$. Penerbit Alfabeta. Bandung.

Sukmadinata, N.S. 2013. Metode Penelitian Pendidikan. PT. Remaja Rosdakarya. Bandung.

Swarjana, Ketut. 2016. Statistik Kesehatan. Percetakan Andi Offset. Yogyakarta.

Watson, Roger. 2002. Anatomi dan Fisiologi untuk Perawat. Perpustakaan Nasional (KDT). Jakarta.

Wisnubrata, Victorbayu. 2016. Ritme Sirkadian Pada Mahasiswa Dengan Pola Tidur Tidak Normal. Skripsi. Universitas Sanata Darma. Yogyakarta.

Wuench, Karl. L. 2019. Skewness and Kurtosis. East California University. USA.

Zarianis. 2006. Efek Suplementasi Besi Vitamin C dan Vitamin C Terhadap Kadar Hemoglobin Anak Sekolah Dasar yang Anemia di Kecamatan Sayung Kabupaten Demak. Tesis. Program Magister Gizi Masyarakat Universitas Diponegoro.

Zufrianingrum, Herina. 2016. Hubungan Antar Hemoglobin dan Kapasitas Vital Paru dengan Daya Tahan Kardiorespirasi Siswa yang Mengikuti Ekstrakulikuler Bola Baket di SMP Negeri 1 Jetis Kabupaten Bantul. Skripsi. Universitas Negeri Yogyakarta. Yogyakarta. 